\title{
Protecting the Children of Haiti
}

\section{Citation}

Balsari, Satchit, Jay Lemery, Timothy P. Williams, and Brett D. Nelson. 2010. “Protecting the Children of Haiti." New England Journal of Medicine 362 (9) (March 4): e25. doi:10.1056/ nejmp1001820.

\section{Published Version}

doi:10.1056/NEJMp1001820

\section{Permanent link}

http://nrs.harvard.edu/urn-3:HUL.InstRepos:30207998

\section{Terms of Use}

This article was downloaded from Harvard University's DASH repository, and is made available under the terms and conditions applicable to Other Posted Material, as set forth at http:// nrs.harvard.edu/urn-3:HUL.InstRepos:dash.current.terms-of-use\#LAA

\section{Share Your Story}

The Harvard community has made this article openly available.

Please share how this access benefits you. Submit a story.

Accessibility 

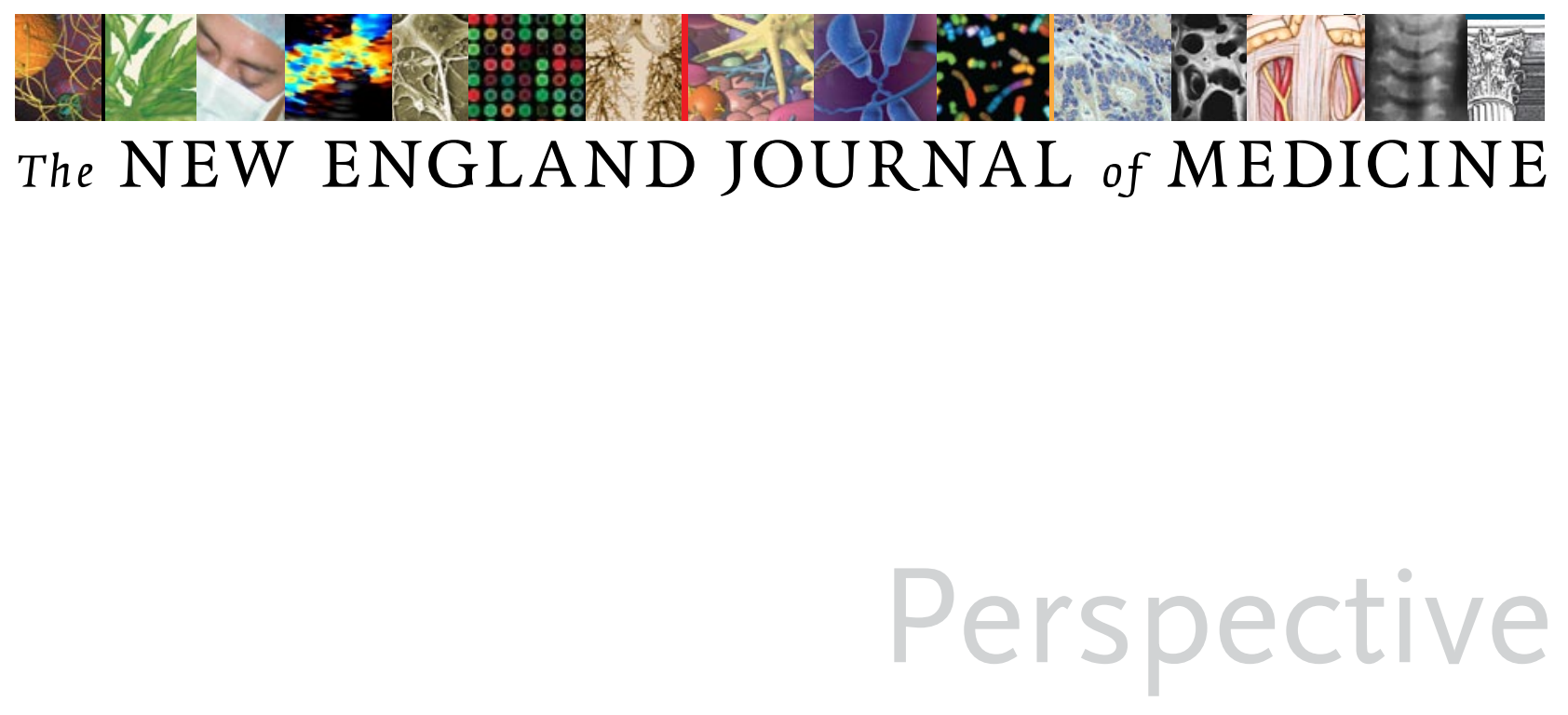

\section{Protecting the Children of Haiti}

Satchit Balsari, M.D., M.P.H., Jay Lemery, M.D., Timothy P. Williams, M.S.W., M.Sc., and Brett D. Nelson, M.D., M.P.H., D.T.M.\&H.

\section{Taiti has long had difficulty in protecting its L children from harm. The earthquake that struck the country on January 12 destroyed much of the capital, Port-au-Prince, as it killed many government}

officials and United Nations (UN) workers and left as many as 230,000 people dead and many thousands injured. In the wake of this sweeping disaster, the plight of Haiti's children has acquired new and terrible dimensions.

On January 24, we went to Haiti as members of a team sent by the François-Xavier Bagnoud Center for Health and Human Rights at Harvard University to conduct a multisite rapid assessment of child-protection needs in the post-earthquake environment, where it was already evident that children were at grave risk of abandonment, abuse, and trafficking. The focus was on the current systems and practices for identifying and caring for unaccompanied children and for trac- ing those who had been separated from their families and reuniting them with parents or guardians. Longer-term interventions to promote the welfare, rights, and safety of this population were also examined.

In 9 days, we interviewed more than 25 stakeholders in Haiti, including government officials, local staff members, humanitarian aid workers, and representatives of domestic and international nongovernmental organizations and UN agencies. We visited field hospitals, clinics, shelters, and orphanages, along with observing risk-assessment practices and participating in meetings of $\mathrm{UN}$ "clusters" (groups focused on individual service sectors).

Children constitute almost half of Haiti's population of 9 million. Before the earthquake, an estimated 350,000 children lived in "orphanages," yet only 50,000 of them had no living parents. ${ }^{1}$ Desperately poor families have often felt compelled to place children in residential care facilities, only to return later and find that they have been given away for adoption. Throughout the world, many families have historically relinquished their children when they reached a tipping point due to unmanageable birth rates; parental death, disability, or unemployment; physical insecurity; displacement; or natural disasters. $^{2}$ In pre-earthquake Haiti, many families had already reached such a crisis.

Local officials estimate that there are about 350 registered orphanages in the country and about twice as many unregistered and unregulated ones. Even most registered institutions do not meet international UN guidelines. A re- 


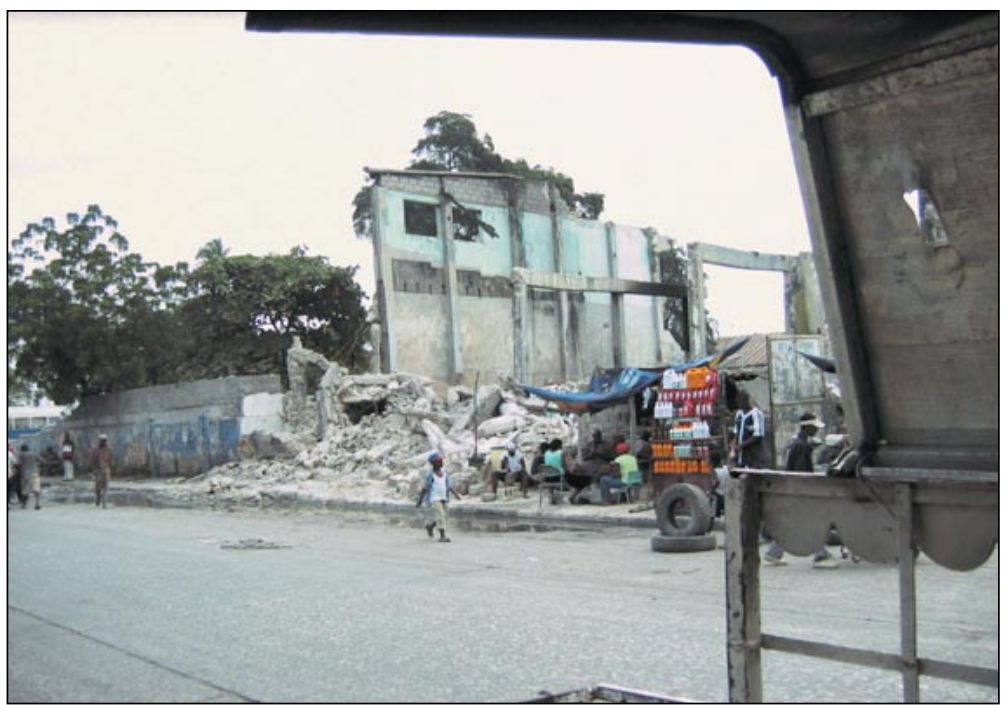

A Young Boy Walks Alone on the Road after the Earthquake in Port-au-Prince.

lated long-standing threat to child protection has been the common practice of sending children away as restavèks (Creole for "stay with") to live with others in exchange for work. An estimated 150,000 to 500,000 restavèks work essentially as unpaid domestic laborers, with little or no access to education or recreation and subject to physical, mental, and sexual abuse. ${ }^{3}$ The restavèk situation and the practice of institutionalizing children reflect the extreme destitution of Haitian families. Thus, the earthquake occurred against a background of economic extremity driving family separation, aggressive trafficking networks, inadequate law enforcement, and a growing global demand for adoptive children.

Parents died and families were splintered as a result of the earthquake. In the rush to provide emergency care, injured adults and children were often scattered, taken to the nearest available health care facilities, and sometimes transferred, without records, to other centers. This situation prevailed for a month, during which time little, if any, demographic or registration information was collected at sites of care or settlement. Critical early opportunities to record, identify, and trace children and families were lost. The lack of data has impaired all aspects of child-protection efforts.

Irregular settlement adds further risk. By January 31, there were 1.1 million Haitians in need of shelter in Port-au-Prince and the surrounding communes, living in 591 documented improvised settlements - some of which, like the Petionville Club, hosted as many as 100,000 refugees. ${ }^{4}$ Children and young people in these dense settlements are easy targets for organized crime, violence, and sexual exploitation.

This disaster has imposed a massive socioeconomic burden on a country that was already struggling with poor governance and an impoverished population. Stripped of all assets by the earthquake, a growing number of families are parting with their children. Given Haiti's unregulated borders, weak law-enforcement practices, and insufficient numbers of international monitors, traffickers face few deterrents. There is growing consternation among child-protection workers about the lack of financial and human resources for protecting Haiti's vulnerable child population, which is estimated by some at 1 million. $^{5}$

The restavè phenomenon and unregulated "orphanages" pose challenges to the placement of unaccompanied children. Although international standard practice is for orphans to be promptly returned to their relatives or communities, the restavek option and severe poverty make communitybased solutions problematic. Many aid workers feel compelled to consider institutional placement as a safer interim solution. But safe institutions are hard to come by. We encountered several hospitals where unaccompanied children whose treatment was complete were not being released for lack of a safe discharge plan (though in the first few weeks after the earthquake, many unaccompanied children had been discharged to the street). Representatives of orphanages visit camps and hospitals daily, and there is no effective mechanism for distinguishing safe residential care facilities from fronts for trafficking.

Adoption is sometimes seen as a viable alternative in the face of destitution. Experience from past disasters and conflicts, however, suggests that adoptions in the immediate wake of such crises carry a high risk of permanent removal of children who are not actually orphans - a practice that inevitably inflames latent nationalist sentiment in the affected region. The fields of child human rights and child psychology place great emphasis on maintaining the integrity of the 
family unit, where children have the best chance of being raised in a loving, intimate environment. There is great need now to provide care for thousands of children, including those with medical and other postoperative needs, and in some instances temporary protection status or adoption across borders might be acceptable. But a much better system for tracing children and protecting borders must first be implemented, to reduce the risk that children will be torn from their own families who, given the means, would nurture and care for them.

Improved family-tracing procedures, border control, effective scrutiny of international adoptions in line with the Hague Convention on Protection of Children and Cooperation in Respect of Intercountry Adoption, and more stringent oversight of orphanages are urgently needed to forestall further abuse. We believe that all aid workers, including voluntary health care professionals, should receive training in child-protection norms and be sensitized to the prevalence of child abandonment, abduction, and trafficking. Child-protection basics, including identification procedures and record keeping, reestablishment of educational opportunities, creation of childfriendly spaces (set up specifically for children in crises to address their physical and psychosocial needs in a stable, trustworthy environment), and health interventions, must be ramped up rapidly. Additional steps must be taken to strengthen local governmental and policing institutions charged with child protection, specifically the Ministry for Social Welfare and Research and the Brigade for the Protection of Minors.

A sustained strategy must be

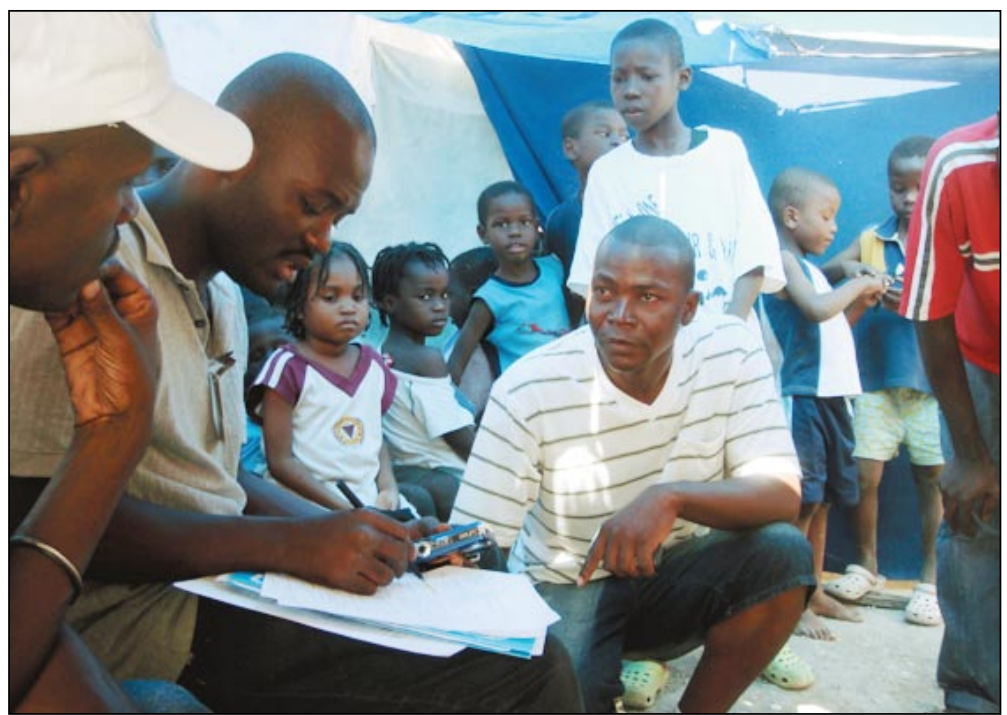

Personnel from Haiti Social Services and the United Nations Children's Fund Visit with Displaced Orphans in One of the Many Tent Cities in Port-au-Prince.

developed to mitigate the distress and insecurity of affected children. The challenges of tracing and family reunification must be addressed through streamlined data-acquisition systems, heightened public awareness, and community-driven monitoring initiatives. Attention to child welfare and disability-related needs is essential, even as economic strategies are found to enable families and communities to achieve a reasonable standard of living. A common refrain heard among aid workers is that to ensure safe childhoods, families must be given a fair chance to be economically viable - which requires investments in health, education, vocational skills, sustainable livelihoods, microfinancing, and improved agricultural practices.

A senior aid worker spoke for many seasoned responders when he said, "We must be firmly committed to this notion of building back Haiti better. We must not accept the restavè phenomenon as the inevitable. We must build a society free of restaveks. Children belong in their communities." This goal will be difficult to achieve. Yet, as the UN's special rapporteur recently remarked, "The human security of every child is of utmost importance to the sustainable development of a society based on human rights and [is] a precondition for sustainable peace." ${ }^{3}$

An imaginative, bold solution is required. Recovery from an earthquake is always complex and slow, but Haiti's children should not be made to wait and suffer. One million vulnerable children are a very large share of Haiti's future and of ours.

Disclosure forms provided by the authors are available with the full text of this article at NEJM.org.

From the François-Xavier Bagnoud Center for Health and Human Rights, Harvard University (S.B., J.L., T.P.W., B.D.N .) and Harvard Medical School (B.D.N.) - both in Boston; and the Division of Emergency Medicine, Weill Cornell Medical College, New York (S.B., J.L.).

This article (10.1056/NEJMp1001820) was published on February 17, 2010, at NEJM.org.

1. Lederer E. UNICEF warns against Haiti child smuggling. The Associated Press. February $9,2010$.

2. Panter-Brick C, Smith MT, eds. Abandoned children. Cambridge, United Kingdom: Cambridge University Press, 2000. 
3. Shahinian G. Report of the Special Rapporteur on contemporary forms of slavery, including its causes and consequences addendum: mission to Haiti A/HRC/12/21/ Add.1. New York: United Nations, September 4, 2009. (Accessed February 16, 2010, at http://www.unhcr.org/refworld/type, MISSION,,,4ac0c6b42,0.html.)

4. International Organisation for Migration. Improving conditions for displaced in Haiti's spontaneous settlements. Press briefing note, January 25, 2010. (Accessed February 17, 2010, at http://www.iom.int/jahia/Jahia/media/ press-briefing-notes/pbnAM/cache/

offonce? entryld=26872.)

5. Sequera V, Fox B. I million children vulnerable. The Associated Press. January 27, 2010.

Copyright $\odot 2010$ Massachusetts Medical Society. 